\title{
The Political Economy of Agricultural Research in Pakistan
}

\author{
MAHMOOD HASAN KHAN ${ }^{*}$
}

\begin{abstract}
This study is premised on the proposition that economic research on agriculture in Pakistan has concentrated on narrow and technocratic aspects without reference to the structure of production relations among various and contending classes of farmers. The paper identifies three major and so far largely unexplored areas of agricultural research, viz. set of relationships among farm groups and their impact on agricultural production and income distribution, measurement and interpretation of participation by these groups in production activities in the private and public sectors, and the land tax system and its effect on issues of growth and equity.
\end{abstract}

"This paper.... argues that the immediate need of Pakistan
is to make available to farmers large quantities of those low-priced
inputs that can bring about large increases in crop production in
relation to the cost incurred." $[68$, p. 223]

"In simpler terms how can economists and other social scientists provide policy guidance within the famework of the current land tenure distribution, rather than expanding their energies seeking futile policies to fight it and, in the process, neglecting policy issues germane to Pakistan's short term opportunities for agricultural growth."

[79, p. 90]

"The main factors responsible for low productivity have been the inadequate supply of vital inputs and the improper management of available resources... It is, therefore, essential that a frontal attack on the problem of low productivity of the agriculture sector include a substantial improvement in the supply of these essential inputs."

[77, p. 49]

\section{WHAT ARE THE REAL ISSUES?}

This paper is essentially a dissent from the technocratic emphasis in research on Pakistani agriculture. ${ }^{1}$ Research on the economics of agriculture in Pakistan,

*Dr. Khan is Professor of Economics at the Simon Fraser University, Canada. While he alone shoulders the entire burden of errors, he thanks Drs. A. Siamwalla and Kenji Okuda for valuable comments on an earlier draft. He is also indebted to an anonymous referee for clarifying one or two important issues.

${ }^{1}$ Agriculture in Pakistan is still the dominant sector of the economy, and most of the people reside in rural areas. Its general performance, and particularly in the food sub-sector, has been uneven. See, for example, Khan [58, p. 3] . 
pursued by Pakistanis and outsiders alike, has concentrated almost exclusively on the need for increased physical inputs and the maintenance of private incentives, without reference to the structure of production relations among various classes of farmers. There are two important aspects of the narrow and economistic view reflected in most of the traditional research. Firstly, it is premised on the false assumption that in agriculture there are linear relations between inputs and outputs, and ignores completely the highly differentiated structure of ownership and control of land, the most important income-earning asset. Secondly, this view has been shared almost without change by influential researchers and policy makers alike during the last thirty years, and, what is more, it is still held uncritically despite a large body of dissenting literature even in the West on orthodox economic theory, at least about the process of economic development. That researchers in Pakistan remain dependent on foreign "expertise", even in identifying research needs to sustain agricultural development, is another sad aspect of the state of research in the country. ${ }^{2}$

It is by now generally agreed that the process of economic development is not simply a problem of resource allocation, as the neoclassical theory assumes and is accepted in Pakistan without reference to the objective relations among various groups in the countryside. Like their counterparts in many other poor countries, researchers and policy makers in Pakistan have recently embraced the rhetoric of "growth with distribution," but their research priorities and policies are guided by distorted perceptions of the real world. They have shown little interest in examining the structure of agrarian relations and its consequences on agricultural development and rural well-being.

An alternative approach to research in identifying the causes of slow and uneven growth of agriculture in Pakistan rests on two central questions. First, who owns and controls land and how are the production relations organized? Secondly how do the different farming regimes affect the use of society's resources and the distribution of the fruits of production? These questions are intimately related to the issues of access to income-earning assets and participation in the process of development. As long as it is pretended that the production process in Pakistan's agriculture involves voluntary choices among independent (and unrelated) economic agents, whose initial endowments matter very little, emphasis in research will remain on issues which provide at best lopsided solutions to the problem of slow economic growth. To understand the nature and persistence of rural poverty, we must start asking the right questions.

It is imperative to reject the politically comfortable world-view held by many on the nature of research needs for sustained agricultural growth in Pakistan. The policy issues "germane" to Pakistan (in both the short and the long runs) are precisely those which the orthodox paradigm assumes away, reflecting not -so-hidden ideological preferences. The "current land tenure distribution" in Pakistan is both inefficient and inequitable. It is this hypothesis which needs testing in order to explore the real causes of the predicament of agriculture, as opposed to the symptoms which have so far been emphasized in research. There are some who, without empirical evidence, have denied even the existence of "large landlords" in Pakistan [16;51; 61]. Excuses for the almost total neglect of research on agrarian structure have included "scarcity" of relevant information and "inhibitive" effects of the land reform policy during the $1972-77$ period. $^{3}$

This paper is premised on the proposition that "large landlords", although small in number, dominate production and distribution systems in Pakistan's agriculture. Also, it challenges the view that these landowners should be accepted as the dominant vehicle for increased production and welfare in the countryside. For one thing, it has not been demonstrated that large landowners in Pakistan are more efficient in allocating their resources than small owners. ${ }^{4}$ Further, it is still to be shown that, in the landlord-tenant regime which coexists with owner-operators in many areas of the Indus basin, the tenant-operated farms work better than small owner-operated units. ${ }^{5}$ To suggest that economic research should be directed mainly at discovering private incentives and structuring public policy for large landowners is to accept at best the undemonstrated. Finally, emphasis on technocratic research, suited to the requirements of large landowners, implies that small farmers (owners and sharecroppers) should be marginalized, and "alternative employment for the rural poor" should be found. ${ }^{6}$ This view is as cynical as it is false.

\section{REVIEW OF ECONOMIC RESEARCH ON AGRICULTURE}

We shall here briefly review the nature of economic research on Pakistan's agriculture during the last thirty years. ${ }^{7}$ Generally, two factors play a central role in

${ }^{3}$ Some researchers have genuinely complained about the absence of published data on land-ownership and tenancy $[8 ; 36 ; 72]$. On the "negative" effects of the 1972 land reforms, one study [89] has been cited in [79], but it was not available to the present author.

${ }^{4} \mathrm{As}$ in some other underdeveloped countries see, for example, [14]-there is evidence in Pakistan that perhaps the contrary is true $[59 ; 60]$.

${ }^{5}$ There is some evidence in Pakistan [58, Chap. 6] that the small owner-operated farms are more efficient than tenant-operated units.

${ }_{7}^{6}$ This position has been taken by the Indus Basin Research Assessment Group [79, p. 90]. ${ }^{7}$ This review is by no means exhaustive, as it does not include papers and reports of all organizations and institutions engaged in agricultural research in Pakistan. It is fair to say that many of these documents do not reflect genuine or quality research. Most of this research is pedestrian, follows the traditional methods of analysis, and focusses on technocratic aspects of agricultural production and marketing. This description applies, by and large, to the Punjab Agricultural University, Sind Agricultural University, the N.W.F.P. Institute of Economic Studies (formerly Peshawar Board of Economic Inquiry), and the Punjab Economic Research Institute (formerly the Punjab Board of Economic Inquiry). For this review, the author has consulted $[41 ; 75 ; 95 ; 96]$. 
determining the nature and quality of research in a country. First, social and economic research is guided mainly by the dominant ideology, and follows a paradigm which this ideology allows to be articulated. Secondly, it is affected by the human and technical infrastructure which a society develops over time. In this review, it will become clear that a particular ideology has dominated the research process in Pakistan, and in this process the country has not become evidently selfreliant even in identifying its research needs for sustained agricultural growth.

Probably the best way to review economic research on agriculture in Pakistan is to discuss it chronologically, as it corresponds roughly to the development of ideas at home and abroad. During the Fifties, much like the generally stagnant conditions in the agricultural sector, there was little systematic research. What existed was a body of highly generalized statements (and euphemisms) on the need to improve farm production and to reform the land tenure system. The infrastructure necessary for academic and applied research was almost nonexistent, although a rudimentary analysis of farm accounts had been done in the Punjab. ${ }^{8}$ During this period, Western economic thought, which dominated the educational system of Pakistan, was centred on the workings of market. While it was admitted that the market had serious failings even in the West, it was an article of faith that private markets alone provided the most efficient mechanism for increased economic welfare to a society. The concessions made to the idea of "planning", or State intervention in the marketplace, in underdeveloped countries were supposed to strengthen private incentives, enterprise, and markets. What the underdeveloped countries needed was "capital formation" to initiate a market-based process of economic development.

Following these ideas in Pakistan, one believed that agricultural production could increase substantially with the use of more physical inputs and with reliance on private incentives. The debate on the agrarian structure (land tenure and taxation), with its likely impact on agricultural production and rural welfare, was conducted mostly inside the government, reflected by a number of reports of various official committees and departments. These reports and statements, however, did not constitute research. They merely reflected the public posture, expressed occasionally in rhetorical language, of governments, and were often apologetic for their failure to do the desired things. Similarly, individual efforts consisted of papers, full of assertions and without theoretical or empirical arguments. It is also significant that, during the Fifties, there were few improvements in the flow of information about farming and related activities. Information on land-ownership and tenancy existed in land revenue records, away from public scrutiny. 9

${ }^{8}$ This is evident from the literature cited in $[95 ; 96]$.

${ }^{9}$ Information published by the government included agricultural prices, land-use and crop statistics, and occasional reports on one or another aspect of agricultural production, marketing, etc.
Somewhat more systematic economic research, though of modest quality, began to appear in the early Sixties for at least two important reasons. First, after the declaration of Martial Law in 1958, Ayub Khan clearly indicated his government's preference for economic growth within a mixed economic system, in which the private sector was to be given special attention and favour. Secondly, limited though the investment in "human capital" still was, by this time a corps of articulate and growth-oriented researchers and bureaucrats had emerged, who were trained almost exclusively within the traditions of Western economic thought and who evidently subscribed to the ideology of development based on private markets. They accepted the not-so-benign role of the State in the economy, probably because it made their positions influential and secure. The decade of the Sixties was dominated by the idea of undifferentiated growth, or "growth now and distribution later." It was marketed through generalized theories and supported by Western economic aid.

Within the private market paradigm, what the agriculture of Pakistan needed were increased physical inputs and price incentives to farmers. The "land reforms" enacted by the Ayub government in 1959 were regarded as a necessary precondition for private enterprise and risk-taking in agriculture. However, it is interesting to note that almost no research was done on the impact of these reforms on redistribution of land and farm productivity. ${ }^{10}$ Initial research in the Sixties concentrated on two basic issues in agriculture. Firstly, it focussed on the problem of supply responses by farmers, i.e. it tested their "rationality". Secondly, it emphasized the impact of increased use of fertilizer, water, etc. on agricultural production. ${ }^{11}$ With the introduction of Mexican seeds of wheat and IRRI rice in the mid-Sixties, euphemistically called the Green Revolution, a plethora of research appeared on the use of these seeds in the Indus basin. The topics ranged from additional inputs to their impact on crop yields and employment. However, almost all of this research was highly aggregate, without examining the impact of new technology at the farm level. ${ }^{12}$ The orthodox bias in research was expressed in seminars and also reflected in the collection of research papers on agriculture at the Pakistan Institute of Development Economics (P.I.D.E.) [ 50; 76] .

In the twilight of the Ayub era, voices were heared on the distributive illeffects of the growth strategy followed by Ayub Khan. However, the problem of income distribution was seen in the context of what were then two separate parts of Pakistan, East Pakistan and West Pakistan $[38 ; 64 ; 65]$. There was still no mention of interclass differences in the distribution of income or income-earning assets in

${ }^{10}$ Only one limited study [13] was published in the Sixties. Reports published by the West Pakistan Land Commission were mainly self-congratulatory and descriptive [100; 101]. Yasin's study [104] of the 1959 land reforms, which appeared in 1972, is not rigorous or even analytical.

A sample of these studies is found in $[25 ; 28 ; 29 ; 31 ; 34 ; 66 ; 67 ; 68 ; 69 ; 87 ; 99]$.

${ }^{12}$ See, for instance, $[24 ; 31 ; 34 ; 52 ; 53]$. 
agriculture. Similarly, there was no discussion of the distributive effects of subsidies provided by the State in the name of private incentives [15; 53]. There was never any reference to the largely regressive land tax system and its consequences on efficiency and equity in the country. ${ }^{13}$ The central issue associated with the new seeds was the provision of complementary inputs and private incentives.

With the exit of Ayub Khan from power in 1969, discussions ensued on the distributive and employment effects of the new seeds. ${ }^{14}$ Failure of the growth strategy pursued by Ayub Khan became manifest in the political turmoil which engulfed Pakistan in the late Sixties. In East Pakistan, it clearly strengthened the hands of the separatists, and in West Pakistan it bolstered the position of the Pakistan People's Party (PPP) which professed populist ideals, couched in socialist phrases. Pakistan's "model" economy, a phrase commonly used in the mid-Sixties, was no longer acceptable to a large number of the contending groups of elite and their associates. It was also the period in which the dominant paradigm of growth in the West, based primarily on private markets and icentives, came under criticism by its own followers all over the world. In the face of persistent poverty, manifest in the growing incidence of unemployment and disparities of income, the neoclassical ideas of gradual (harmonious), continuous and cumulative growth sounded altogether untenable. Many of the mainstream economists and policy makers started entertaining the notion of distributive justice with growth. The problem of persistent poverty was then accommodated in phrases like "growth with distribution", "basic needs", "target groups", etc. Much of the development literature in the West, as in the former colonies, began focusing on growth with distribution.

In Pakistan, events were moving fast. The socialist rhetoric of the PPP reflected new priorities from at least the end of 1970 . The PPP formed the national government after the separation of Bangladesh in December 1971. Among other things, the new government launched a series of reforms and moved to broaden public control of the economy [40]. In agriculture, it promulgated a land reform programme in early 1972, and by the mid-Seventies it had nationalized several private-sector activities. The important thing to note here is that there was almost no research on the policies adopted by the PPP soon after it took power. This was true generally throughout the period of its rule.

The issue of growth with distribution did not, by and large, catch the fancy of most researchers on Pakistan agriculture, although a beginning had been made in the debate on East Pakistan versus West Pakistan just before the civil war in 1971. Most of the research efforts were still being expended on the technocratic aspects of the process of adoption of new seeds of wheat and rice, particularly in the Punjab $[1 ; 4 ; 12 ; 23 ; 27 ; 49 ; 54 ; 63 ; 73 ; 82 ; 88]$. There were three important aspects of

${ }^{13}$ As a part of the investigation of the tax system of Pakistan, the Taxation Enquiry Committee Report included discussion on direct taxes in agriculture [80] ${ }^{4}$ See $[33 ; 35 ; 53]$ research on the Green Revolution. Firstly, it consisted mainly of doctoral dissertations completed at universities in the U.S.A. Secondly, they focussed on the impact of new technology on agricultural production and incomes, without taking into account differences in participation by various farm groups. The only structural dimension they incorporated was farm size. Thirdly, these studies contained quantitative analysis of resource allocation and productivity at the farm level, in contrast with earlier studies which were highly aggregate and used simple techniques.

A somewhat detailed discussion of the distributive aspects of the Green Revolution, and of rural poverty in general, appeared in the literature on Pakistan's agriculture mainly outside the country. It clearly reflected the changing perspec tives on growth and distribution in several underdeveloped countries $[36 ; 57 ; 74]$ While the issue of "divisible" and "indivisible" packages of technology, especially about tractors and tubewells and their impact on farm employment, was now in the forefront, there was still no study of land-ownership in relation to the use of resources and income distribution. Only two aggregate studies on the question of agricultural taxation and intersectoral transfer of resources were published in the early Seventies $[43 ; 62]$. Some preliminary studies were undertaken on the nature of poverty, the effect of the Green Revolution on income distribu tion, and the cost of living of agricultural workers. ${ }^{15}$ There was also an exploratory study of the likely effects of the land reform of 1972 on the redistribution of land [47] . ${ }^{16} \mathrm{~A}$ general discussion on the land tax system of the country advanced somewhat the arguments which were first presented in $1970[3 ; 19 ; 44 ; 84]$. Except for these, however, studies on tubewells, prices and markets continued with traditiona fervour $[2 ; 3 ; 10 ; 18 ; 21 ; 26 ; 81 ; 83 ; 85]$. An "Abstract" of research published by the P.I.D.E. in mid-1974 clearly emphasized the orthodox issues, though it included some "institutional" projects [75] .

It was in the latter half of the Seventies that a number of studies, some expanding on previous statements and hypotheses and others exploring the issues on a limited basis, focussed on rural poverty, income distribution, tractorization, and land tenure distribution $[5 ; 8 ; 36 ; 39 ; 46 ; 48 ; 70 ; 72 ; 94 ; 97 ; 102]$. Most of these studies were conducted either by outsiders or outside Pakistan. A much larger number of research studies still concentrated on issues within the neoclassical framework. They dealt with the use of inputs, productivity levels by farm size, and application of linear programming models to resource allocation in the Punjab $[9 ; 17 ; 37 ; 42 ; 55 ; 56 ; 90 ; 91 ; 92 ; 93 ; 103]$.

${ }^{15}$ See $[20 ; 22 ; 32 ; 71]$

${ }^{16}$ This study was based on fragmentary data on land-ownership, and relied on many unrealistic assumptions for extrapolating the likely effects of the 1972 land reforms on redistribution of land. A recent paper by Herring [46] is perhaps more interesting. 
It is significant that economic research during the PPP rule from 1972 to 1977 was not directed to the analysis of controls and reforms which the party leadership introduced in the country. While numerious public statements were made and position papers written on policies adopted by the PPP government, there was no systematic and critical study of the changes being sought or introduced. ${ }^{17}$

Also, little information was ever released to the public on the structure of ownership and control of land. Likewise, the research establishment showed no interest in information on problems of agricultural taxation, rural income distribution, consumption patterns, and participation by various farm groups in the process of development. The data collected in the official surveys and in the 1972 Agricultural Census were quite unsuitable for analysing these problems.

Since the removal of the PPP government from power in mid-1977, several public statements on the so-called negative effects of policies followed by the PPP have appeared..$^{18}$ The new government has launched some well-publicized "crash" programmes to recover from the slow and uneven growth experienced by agriculture in the preceding years. The emphasis in these programmes is on the supply of physical inputs to farmers, combining the major elements of the technocratic approach of the Sixties and discrediting the "interventionist" policies of the PPP in the Seventies. While the rhetoric on rural poverty has become part of the tradition, there are clear signs of increased reliance on the delivery of inputs through the markets, with support by the public sector through price incentives and provision of agricultural extension services. It is within this "pragmatic" strategy of growth that the research priorities to revive Pakistan's agriculture are being defined. Its most explicit formulation appears in the Report of the Indus Basin Research Assessment Group [79]. It emphasizes the production potential of the Indus basin, "the great food machine", and stresses the need to provide physical inputs and appropriate infrastructure within the existing land tenure system. ${ }^{19}$ A somewhat similar conclusion has been drawn in a research report by the P.I.D.E. on the state of the economy in the Seventies [77]. Here, it should also be pointed out that current research on agriculture in Pakistan shows almost no interest in formulating reasonable hypotheses on the policies of "Islamization" being introduced by the government. ${ }^{20}$

${ }^{17}$ To this, there was perhaps one exception, related to the study of the Integrated Rural Development Programme [86].

${ }^{18}$ See, for example, [79, p. 90 ; and 78 , pp. 1-2]

19 While the report has defined Pakistan's agricultural research priorities $[79$, pp. 91-106] in almost the same way as pursued in the Sixties, it has appropriately criticised the low quality of research being done in most public institutions in Pakistan.

${ }^{20}$ This applies equally to (a) the divergent views of Islamic scholars, and economists, on the ownership and control of land, and (b) the introduction of ushr in agriculture by the present government. One recent study of $u$ shr by Zahid [106] is a pleasant exception.

\section{THE AGRARIAN STRUCTURE OF PAKISTAN}

The agrarian structure of Pakistan is highly differentiated and, in turn, the relations on land are evidently asymmetrical. Admittedly, changes in the ownership and control of land have been induced by public policy and market forces. What is, how ever, significant is that these changes have not been altogether propitious to sustained increase in economic welfare in the countryside. It seems highly improbable that the existing agrarian structure can encourage sustained agricultural development. For one thing, given the differentiated ownership and control of land and related assets, a majority of farmers (peasants) do not have equitable access to inputs and infrastructural services. Also, large farms are not necessarily more efficient than small farms, and among small farms, the owner-operated units are perhaps more efficient than tenant-operated parcels.

Recent research, which is by no means exhaustive, on the ownership and control of land in Pakistan, and in the Indus basin in particular, reveals some disturb ing features. ${ }^{21}$ As shown in Tables 1 and 2, the concentration of land-ownership in all regions, except in the N.W.F.P., is very high. Secondly, a high proportion of farmers are marginal owners and share-croppers, the former being numerous in the Punjab and the N.W.F.P. and the latter in Sind. There are also some significant interregional differences in the Indus basin.

1. Land-ownership is more concentrated in Sind than in the Punjab, although in both provinces there has been some reduction in ownership by large land-owners.

2. The number of marginal owners and their area have increased significantly in the Punjab, but the share of all other classes of owners (except small owners in Sind) has declined. Apparently, a substantial proportion of the area of large farms in Sind has been transferred to small and marginal owners, but in the Punjab most of it has gone to large land-owners.

3. Access to the use of land has been less restricted in Sind than in the Punjab, because of the extensive use of share-croppers (haris) by owners of large and very large land holdings in the former province. In the Punjab, on the other hand, there is evidence of greater concentration of land use, and the gains have been made mainly by medium and large owners who now rent land from marginal owners. The trend toward greater concentration of land use among larger farmers is supported by increasing cultivation by owners themselves of medium and large holdings in the Punjab. A similar trend has recently emerged in Sind.

${ }^{21}$ This discussion is based primarily on [58]. Also, see [45;102]. 
4. Increasing proportions of marginal and small farms, especially among the owner-operated ones in the Punjab, became fragmented in the Seventies, though fragmentation of large farms did not increase.

Table 1

Distribution of Land-ownership in Pakistan and Provinces, 1976

\begin{tabular}{|c|c|c|c|c|c|c|c|c|}
\hline \multirow{6}{*}{ Farm Size } & \multicolumn{2}{|c|}{$\begin{array}{c}\text { Pakistan } \\
(0.55)\end{array}$} & \multicolumn{2}{|c|}{$\begin{array}{l}\text { Punjab } \\
(0.52)\end{array}$} & \multicolumn{2}{|c|}{$\begin{array}{l}\text { Sind } \\
(0.58)\end{array}$} & \multicolumn{2}{|c|}{$\begin{array}{c}\text { N.W.F.P. } \\
(0.48)\end{array}$} \\
\hline & Percent & - Percent- & Percent- & Percent- & Percent- & Percent- & Percent- & - Percent \\
\hline & age & age & age & age & age & age & age & age \\
\hline & of & of & of & of & of & of & of & of \\
\hline & Owners & Owned & Owners & Owned & Owners & Owned & Owners & Owned \\
\hline & & Area & & Area & & Area & & Area \\
\hline Marginal & 70.8 & 24.9 & 69.0 & 26.0 & 40.4 & 8.2 & 85.9 & 40.8 \\
\hline Small & 17.5 & 21.3 & 19.6 & 24.3 & 23.9 & 12.4 & 8.6 & 19.7 \\
\hline Medium & 7.6 & 18.1 & 7.8 & 18.6 & 17.6 & 18.3 & 3.8 & 13.3 \\
\hline Large & 2.6 & 13.2 & 2.3 & 12.7 & 10.1 & 19.2 & 1.1 & 8.1 \\
\hline Very Large & 1.5 & 22.8 & 1.2 & 18.2 & 8.0 & 42.0 & 0.6 & 18.1 \\
\hline
\end{tabular}

Source : [58, Chap. 3].

Notes: (a) Figures in parentheses are values of the Gini Coefficient.

(b) The classification of farms is as follows :

Marginal: $\quad 6.25$ acres or less

Small: more than 6.25 to 12.5 acres

Medium: more than 12.5 to 25.0 acres

Large: more than 25.0 to 50.0 acres

Very Large: more than 50.0

The land system in the Indus basin is in a state of transition from a predominantly "feudal" to "capitalist" agriculture, increasingly assuming a marketoriented character. ${ }^{22}$ There are three salient features of this transition.

Firstly, in several areas of Sind and in some areas of the Punjab, semi-feudal relations on land still dominate. They exhibit two basic characteristics: (i) a high

${ }^{22}$ On the origins and nature of the land tenure systems which Pakistan inherited from the British India, there has been an interesting debate amongst social scientists. A Marxist analysis of the land system of British India has been done recently by Alavi $[6 ; 7]$
Table 2

Distribution of Self-Cultivating Owners in the Punjab and Sind, 1976

\begin{tabular}{lcccc}
\hline & \multicolumn{2}{c}{ Punjab } & & \multicolumn{2}{c}{ Sind } \\
\cline { 2 - 5 } Farm Size & $\begin{array}{c}\text { Percentage } \\
\text { of Self- } \\
\text { cultivating } \\
\text { Owners }\end{array}$ & $\begin{array}{c}\text { Percentage } \\
\text { of Owner- } \\
\text { cultivated } \\
\text { Area }\end{array}$ & $\begin{array}{c}\text { Percentage } \\
\text { of Self- } \\
\text { cultivating } \\
\text { Owners }\end{array}$ & $\begin{array}{c}\text { Percentage } \\
\text { of Owner- } \\
\text { cultivated } \\
\text { Area }\end{array}$ \\
\hline Marginal & 76.0 & 72.9 & 87.1 & 88.4 \\
Small & 71.4 & 68.6 & 84.2 & 84.7 \\
Medium & 61.9 & 65.1 & 68.2 & 67.7 \\
Large & 63.0 & 61.7 & 45.8 & 44.1 \\
Very Large & 39.0 & 40.5 & 8.0 & 8.6 \\
All Sizes (Average) & 73.3 & 64.5 & 72.8 & 42.7 \\
\hline
\end{tabular}

Source: $\quad[58$, Chap. 3$]$

Note: $\quad$ Farms are classified as in Table 2.

concentration of land-ownership in the form of large estates in the hands of a relatively small number of owners, and (ii) a "feudal" tenancy with some absentee landlords and intermediate interests, in which the land is leased out in small parcels to a large number of landless share-croppers on a share-in-kind basis.

Secondly, a certain decline in "feudal" tenancy has been replaced by commercialized agriculture, based on hired labour and machines. This has resulted partly from resumption of land from tenants for cultivation by landlords themselves. The tenant-operated farms have decreased and land use has become more concentrated. At the same time, there has emerged a new type of commercial tenancy in the central and eastern districts of the Punjab and in parts of Sind (Hyderabad and Nawabshah districts). Land is leased out by small and marginal owners to rich peasants and large land-owners. Even if there was reduction in the concentration of land-ownership due to the land reforms of 1959 and 1972, the concentration of operational holdings has evidently increased. This was induced perhaps by the high private profitability of the new technology associated with the Green Revolution. 
Thirdly, small marginal owner-operators have assumed a significant numerical weight. Their numbers have increased impressively, especially in the Punjab, for several reasons. Some of these are: decline in feudal tenancy and increased commodity relations; development of a market economy; changes in property relations due to rapid population growth and laws of inheritance; and land reform measures of the Sixties and the Seventies. As the small and marginal owners must work partly as tenants, they lease out their lands to larger land-owners.

This brief outline reveals three distinct sectors, coexisting but contending with each other. The first sector is the oldest of the three, dominated by quasi-feudal relations between landlords and share-croppers. While the strength of this sector has declined in some districts of the Punjab, it still remains quite powerful in Sind. A high concentration of land-ownership has continued, despite the claims to the contrary in the land reforms of 1959 and 1972 . The only major change observed in the landlord-tenant nexus since the early Seventies has been that of heightened tensions between the two parties. While social equilibrium is maintained on the surface by the police and judiciary of the State, production relations have been affected adversely in several areas. For instance, the "revolution of rising expectations" among the haris in Sind seems to have turned into an experience of rising frustrations for them and increased fear for their landlords.

The second sector comprises a mass of small and medium cultivating owners, who use mainly their family labour. This sector is dominant in many areas of the Punjab, but small and of recent origin in Sind. Many of these owner-operators owe their existence to settlement schemes and land reform programmes. Production in this sector is still largely for family consumption, although more of it is now marketoriented. Capital is both scarce and difficult of access. These peasants have often been left out from the aid and subsidy programmes of the government. In many areas of the Punjab, the coexistence of large and "enterprising" farmers is a major source of further squeeze on small and marginal owner-operators. The highly imperfect markets for inputs and outputs tend to interact with State policies in accentuating disparities in income-earning opportunities.

The third sector is the most recent one. It comprises large land-owners and rich peasants, with access to new technology and markets. We see in this sector the burgeoning capitalist relations of production, in which the owner hires wage labour to work with land and machines. These farmers enjoy the highest and the most visible place in the development programmes of the government, as they also exert the greatest influence on markets and public sector services. They were at the centre of the "bimodal" strategy of development in the Sixties, which is being advocated strongly by some in the country today. It must be stressed that the capitalist relations have not become exclusive in this sector. It still retains many remnants of pre-capitalist agriculture. It has made serious inroads probably in the central and eastern regions of the Punjab and acquired some strength in Hyderabad and Nawabshah districts of Sind.

\section{RESEARCH PRIORITIES REDEFINED}

The discussion in Sections II and III clearly suggests that research on Pakistan's agriculture needs radical reorientation. The suggestion here is not that all traditional research should be abandoned. However, since Pakistan has a highly differentiated agrarian structure, the narrow and largely technocratic approach ignores the asymmetry of relations among various farm groups. The technocratic approach is premised on an ahistorical economic theory: it denies the formation of classes on land as a historical (dialectical) process. The asymmetry of the landlord with his share-cropper (hari) and the differentiation of the kulak from the subsistent peasant are historical formations of production relations which are responsible for both underdevelopment of agriculture and treatment of small peasants as only marginal. It must be stressed that the differentiated agrarian structure, mainfest in the asymmetrical relations among the classes on land, is itself a barrier to the rapid expansion of agriculture.

Rural development efforts, through either country-wide or specific-area projects, to persuade farmers to adopt modern inputs and to grow new crops, tend to exclude a large number of peasants in Pakistan. In government-sponsored agricultural schemes, as in the market-place, participation is greatly affected by the ownership and control of land and related assets. In many development projects, established assumedly to involve a majority of farmers, the "target groups" are not the major beneficiaries. On the contrary, they become the victims of the consequent "development". Their numbers grow as 'marginalized' small owners, displaced tenants or share-croppers, and wage workers.

Two crucial areas of research have been identified in this paper, but these have been ignored by researchers and policy makers in Pakistan. The first relates to the analysis of the complex interrelations among the various and contending farm groups and their impact on agricultural production and income distribution. Here we should not merely be concerned with the landlord-tenant nexus, complex and interesting though it still is. We should also include in this area a systematic study of wage labourers in agriculture. Who are these workers? By what process are they being created as a relatively new and growing class? How are their wages determined? How do they compare with landless tenants and marginal owners? Our knowledge of rural labour, its working conditions and wages, and the working of the rural labour markets in Pakistan is pitifully meagre [58, pp. 206-209].

The second area covers the measurement and interpretation of participation by these groups in production-related activities, in both the private and public sectors. For illustration here, four distinct groups can be identified:

1. "large" land-owners, who may be landlords dependent on tenants (or share-croppers), or capitalist farmers using machines and hired labour; 
2. "small" land-owners, who may be owner-operators or part-tenants producing mainly for subsistence;

3. "share-croppers", working on others' land in small parcels and sharing output in kind (or cash); and

4. "wage labour", who are hired on temporary or permanent basis and receive their wage in kind or cash.

It is also necessary to clearly identify the relevant production relations among these groups and activities (be they in the private of in the public sector) in which differentiated participation is clearly observed. Some obvious activities are:

(a) purchase of physical inputs (seeds, fertilizer, pesticides);

(b) purchase of or access to irrigation water (canal and tubewell);

(c) purchase of or access to farm machinery;

(d) access to farm credit, its terms and collateral requirements;

(e) access to agricultural extension services, including contacts with extension agents and acquisition of physical inputs through them;

(f) access to markets for crop output, including measure of surplus, transportation, dealers and terms of disposal of surplus;

(g) existence of and access to cooperative organization;

(h) landlord-tenant contracts, including shares, costs, labour, and

(i) employment of wage labour, including wages and terms.

Research in these areas has a direct bearing on policies about participation by the "target groups" in agricultural development. It will highlight not only the central but intricate relations among various farm groups, but also the structure of private and public sector activities in relation to the participation they allow these groups.

One last and important area of research in agriculture, which has not been explored in Pakistan, is the land tax system and its impact on production and income distribution. In an economy in which agricultural production must be expanded rapidly, the role of direct taxes for capital formation cannot be over-emphasized. Occasionally, by design and often by default, governments have allowed transfer of agricultural surplus to other sectors without, at the same time, returning to agriculture the benefit of investible resources for its own development. Further, mainly by design and sometimes by default, public policies for the agricultural sector have helped only certain groups to appropriate the benefits of growth without using fiscal instruments to redistribute these gains to other groups. Even if the gains have resulted from private risk-taking and investment, mobilization of surplus and redistribution of income through direct agricultural taxation have been the most neglected areas of research and public policy. For this there are many reasons. For one thing, taxes in any form, and direct taxes in particular, are unpopular. Land revenue in Pakistan is the most ancient form of tax, and it is the only direct tax on agriculture. There are several indirect (and some hidden) taxes by which the agricultural surplus is transferred to other sectors of the economy. Continuing dependence on indirect taxes on agriculture reflects the unwillingness or inability of governments to impose direct and progressive taxes. Apparently, the political and administrative advantages of indirect taxes have far exceeded their adverse effects on efficiency and equity within agriculture and between this and other sectors.

The rigid tax structure of the land revenue system in Pakistan (and, therefore, the unchanging amount of collected revenue), is clearly reflected by its declining share in provincial taxes and revenues. In Table 3, the share of direct agricultural tax (land revenue, cesses, and surcharge) in provincial taxes fell from 41 percent in 1965 to 14 percent in1979. Likewise, its share in provincial revenues declined from 15 percent to 8 percent in the same period. A more dramatic fall was in the ratio of this tax to agricultural income - from 1.5 percent to 0.4 percent. These reductions are particularly significant in view of the fact that the land revenue rates were increased quite sharply in the late Seventies. Another serious aspect of the land tax system has been that, at least until 1977, the revenue per acre differed very little between land holdings of various sizes: the rate did not vary with the size of one's holding. The so-called agricultural income tax is a surcharge on land revenue and allows a high exemption based on the amount of the land revenue paid. Therefore, the collections have remained low and stable.

The tax base has shrunk even with the ad hoc increases in the land revenue rates in recent years. While agricultural incomes have risen, the burden of direct taxation has fallen considerably. Agricultural output has expanded just as the prices of all agricultural goods have been rising. The combination of output and price increases, unprecedented in Pakistan, has resulted in substantial new incomes for at least those with large holdings. The land tax system has, however, not responded to these changes. In the absence of a progressive and direct tax on agricultural incomes, investible resources remain in the hands of those whose incomes have increased because of their monopoly on land and the subsidies provided by the State in the name of incentives for increased production. Also, it is not certain if the recipients of new incomes, among the large land-owners, are necessarily the most efficient users of society's resources. The present tax structure then maintains horizontal inequity within agriculture as it apparently subsidizes inefficiency. 
Table 3

Relationship of Direct Agricultural Taxes to Agricultural Income and Provincial Revenues, Selected Years

\begin{tabular}{cccc}
\hline Year & \multicolumn{3}{c}{ Direct Agricultural Taxes as Percentage of } \\
\cline { 2 - 4 } & $\begin{array}{c}\text { Agricultural } \\
\text { Income of the } \\
\text { Country }\end{array}$ & $\begin{array}{c}\text { Total } \\
\text { Provincial } \\
\text { Taxes }\end{array}$ & $\begin{array}{c}\text { Total } \\
\text { Provincial } \\
\text { Revenues }\end{array}$ \\
\hline $1964-65$ & 1.48 & 41.2 & 14.6 \\
$1968-69$ & 1.23 & 33.1 & 13.5 \\
$1972-73$ & 0.75 & 25.7 & 13.1 \\
$1976-77$ & 0.32 & 10.7 & 5.6 \\
$1977-78$ & 0.37 & 14.1 & 7.6 \\
\hline $1978-79$ & 0.37 & 14.1 & 7.5 \\
\hline
\end{tabular}

$\begin{array}{ll}\text { Source: } & \text { [58, p. 273]. } \\ \text { Note: } & \text { Direct Agricultural Taxes include land revenue, cesses, and surcharge on land revenue }\end{array}$ (income tax).

\section{CONCLUSION}

The paper can be concluded with three important observations on agricultural economic research in Pakistan. Firstly, there is need to relex the grip of secrecy on data and information related to land records, taxation, and rural infrastructure. It also means that public agencies collecting and keeping such data should be made more sensitive to the needs of genuine research on conditions of life in rural areas. Secondly, emphasis on research infrastructure should not be on building new empires, like new research institutes etc., but on creating training facilities and work environments which can make Pakistani researchers critical and self-reliant. The reward structure should not glamorize only the traditional and orthodox methods of research: it should encourage the use of new and bolder perspectives. Finally, the policy of "building on the best" in research, as in policy making, has far too long concentrated on the problems of agriculture in the Indus basin, and particularly the Punjab. Research problems of other areas, particularly Baluchistan and the N.W.F.P., deserve strong commitment for at least two reasons. For one thing, their agricultural problems are in many ways more complex and intractable. For another, there is the problem of information and data on these problems. There exists a definite challenge for economic research outside the Indus basin, but the research infrastruc ture is either non-existent or preoccupied with glamorous and "rewarding" research.

\section{REFERENCES}

1. Afzal, M. "Implications of the Green Revolution for Land Use Patterns and Relative Crop Profitability Under Domestic and International Prices". Pakistan Development Review. Vol. XII, No. 2. Summer 1973. pp. 135-147.

2. Afzal, M. "Statistical Estimation of Useful Life of Tubewells". Pakistan Development Review. Vol. XII, No.1. Spring 1973. pp. 81-90.

3. Afzal, M., et al. The Pricing of Agricultural Capital Inputs in Pakistan. Islamabad: Pakistan Institute of Development Economics. 1974. (Monograph No. 18)

4. Ahmad, B. "Farm Mechanization and Agricultural Development: A Case Study of the Pakistan Punjab". Unpublished Ph. D. Thesis. Michigan State University. 1972.

5. Alauddin, T. "Mass Poverty in Pakistan: A Further Study". Pakistan Development Review. Vol. XIV, No.4. Winter 1975. pp. 431-450.

6. Alavi, H. "India: Transition from Feudalism to Colonial Capitalism". Journal of Contemporary Asia. Vol. XI, No. 4. 1980. pp. 359-399.

7. Alavi, H. "Structure of Peripheral Capitalism". 1980. Mimeographed. Forthcoming in Introduction to Sociology of the 'Developing Societies' (Edited by T. Shanin and H. Alavi).

8. Alavi, H. "The Rural Elite and Agricultural Development in Pakistan". In R.D. Stevens, et al. (Editors), Rural Development in Bangladesh and Pakistan. Honolulu: University of Hawaii Press. 1976. pp. 317-353.

9. Aslam, M. M. "Some Comparative Aspects of Production and Profit Functions: Empirical Applications to a Punjab District". Pakistan Development Review. Vol. XVII, No. 2. Summer 1978. pp. 191-211.

10. Azhar, B. A. "An Econometric Analysis of Price Behaviour in Pakistan". Pakistan Development Review. Vol. XII, No. 4. Winter 1973. pp. 375-386.

11. Azhar, B. A. "Land Revenue Assessment: A Case Study". Pakistan Development Review. Vol. XII, No. 3. Autumn 1973. pp. 232-246.

12. Azhar, B. A., et al. "A Model for Forecasting Wheat Production in the Punjab". Pakistan Development Review. Vol. XII, No. 4. Winter 1973. 
13. Berringer, C. "Welfare and Production Efficiency: Two Objectives of Land Reform in Pakistan". Pakistan Development Review. Vol. II, No. 2. Summer 1962. pp. 173-188.

14. Berry, R. A., and W. R. Cline. Agrarian Structure and Productivity in Developing Countries. Baltimore, Maryland: Johns Hopkins Press. 1979

15. Bose, S. R., and E. H. Clark, II. "Some Basic Considerations on Agricultural Mechanization in Pakistan”. Pakistan Development Review. Vol. IX, No. 3. Autumn 1969. pp. 273-308.

16. Burki, S. J. "The Development of Pakistan's Agriculture: An Interdisciplinary Explanation". In R.D. Stevens, et al. (Editors), Rural Development in Bangladesh and Pakistan. Honolulu: University of Hawaii Press. 1976. pp. 290-315.

17. Chaudhary, M. A. "Determination of Cost of Tubewell Water and Estimation of Economic Rent in Canal Irrigation”. Pakistan Development Review. Vol. XVIII, No. 2. Summer 1978. pp. 139-168.

18. Chaudhry, M. G. "Problem of Agricultural Taxation in West Pakistan and an Alternative Solution”. Pakistan Development Review. Vol. XII, No. 2. Summer 1973. pp. 93-122.

19. Chaudhry, M. G. "Rural Income Distribution in the Green Revolution Perspective”. Pakistan Development Review. Vol. XII, No. 3. Autumn 1973. pp. 247-258.

20. Chaudhry, M. G., and A. R. Kemal. "Wheat Production Under Alternative Production Functions”. Pakistan Development Review. Vol. XIII, No. 2. Summer 1974. pp. 222-226.

21. Chaudhry, M. G. and M. A. Chaudhry. "Cost of Living Indexes for Rural Labourers in Pakistan”. Pakistan Development Review. Vol. XIII, No. 1. Spring 1974. pp. 26-35.

22. Chaudhry, M. A. "Impact of Optimal Cropping Patterns on Incomes in a Punjab District”. Pakistan Development Review. Vol. XV, No. 2. Summer 1976. pp. 222-230.

23. Clark, E. H. II. "The Development of Tubewell Irrigation in the Punjab. A Investigation into Alternative Modes of Groundwater Development”. Unpublished Ph. D. Thesis. Princeton University. 1972.

24. Cownie, J., B. F. Johnston, and B. Duff. "The Quantitative Impact of the Seed-Fertilizer Revolution in West Pakistan: An Exploratory Study". Food Research Institute Studies. Vol. IX, No. 1. 1970. pp. 57-75.

25. Dorfman, R., R. Revelle, and H. Thomas. "Waterlogging and Salinity in the Indus Plain: Some Basic Considerations". Pakistan Development Review. Vol. V, No. 3. Autumn 1965. pp. 331-370.

26. Eckert, J. B. "The Impact of Dwarf Wheats on Resource Productivity in West Pakistan's Punjab". Unpublished Ph. D. Thesis. Michigan State University. 1970.
27. Eckert, J. B. "Private Tubewell Numbers in Pakistan: A Synthesis". Pakistan Development Review. Vol. XIII, No. 1. Spring 1974. pp. 94-105.

28. Falcon, W. P. "Farmer Response to Price in a Subsistence Economy: The Case of West Pakistan". American Economic Review. Vol. 54, No. 3. 1964. pp. 580-591.

29. Falcon, W. P., and C. H. Gotsch. "Agriculture in West Pakistan: An Analysis of Past Progress and Future Prospects”. Karachi: (Pakistan) Institute of Development Economics. December 1964. (Mimeographed)

30. Falcon, W.P., and C. H. Gotsch. "Relative Price Response, Economic Efficiency, and Technological Change”. In W. P. Falcon and G. F. Papanek (Editors), Development Policy II - The Pakistan Experience. Cambridge, Mass: Harvard University Press. 1971. pp. 165-180.

31. Gotsch, C. H. "A Programming Approach to Agricultural Policy Planning in West Pakistan”. Pakistan Development Review. Vol. VIII, No. 2. Summer 1968. pp. 192-225.

32. Gotsch, C. H. "Economics, Institutions and Employment Generation in Rural Areas”. In E. O. Edwards (Editor), Employment in Developing Nations. New York: Columbia University Press. 1974. pp. 133-162.

33. Gotsch, C. H. "Notes on the Current Status and Future Development of West Pakistan Agriculture”. Harvard University Development Advisory Service Report No. 218. May 1972.

34. Gotsch, C. H. "Regional Agricultural Growth: The Case of West Pakistan". Asian Survey. Vol. VIII, No. 3. 1968. pp. 188-205.

35. Gotsch, C. H. "Technology, Prices and Incomes in West Pakistan Agriculture: Some Observations on the Green Revolution". Harvard University Development Advisory Service Report No. 199. October 1971. (Mimeographed)

36. Gotsch, C. H. "The Green Revolution and Future Development in Pakistan". In R. D. Stevens, et al. (Editors), Rural Development in Bangladesh and Pakistan. Honolulu: University of Hawaii Press. 1976. pp. 354-383.

37. Gotsch, C.H., et al. "Linear Programming and Agricultural Policy: Micro Studies of the Pakistan Punjab”. Food Research Institute Studies. Special Issue. Vol. XV, No. 1. 1975. pp. 1-106.

38. Griffin, K., and A. R. Khan (Editors). Growth and Inequality in Pakistan. New York: St. Martin's Press. 1972.

39. Guisinger, S., and N. L. Hicks. "Long-Term Trends in Income Distribution in Pakistan”. World Development. Vol. 6, Nos. 11-12. 1978. pp. 1271-1280.

40. Gustafson, W.E. "Economic Reforms Under the Bhutto Regime". Journal of A sian and African Studies. Vol. VIII, Nos. 3-4. 1973. pp. $242-258$.

41. Gustafson, W. E. (Editor). Pakistan and Bangladesh: Bibliographic Essays in Social Science. Islamabad: University of Islamabad Press. 1976. 
42. Hamdani, K., and N. U. Haque. "The Demand for Fertilizer: A Critical Review”. Pakistan Development Review. Vol. XVII, No. 4. Winter 1978. pp. $451-467$.

43. Hamid, J. "Suggested Approach to Agricultural Taxation Policy in West Pakistan”. Pakistan Development Review. Vol. X, No. 4. Winter 1970. pp. $422-447$.

44. Hamid, J. "The Problem of Agricultural Taxation in West Pakistan and an Alternative Solution: A Comment". Pakistan Development Review. Vol. XII, No. 3. Autumn 1973. pp. 311-314.

45. Hamid, N. "Process of Agricultural Development - A Case Study of the Punjab". Unpublished Ph. D. Thesis. Stanford University. 1981

46. Herring, R. J. "Zulfikar Ali Bhutto and the Eradication of Feudalism in Pakistan”. Comparative Studies in Society and History. Vol. XXI, No. 4. 1979. pp. 519-557.

47. Herring, R. J., and M. G. Chaudhry. "The 1972 Land Reforms in Pakistan and Their Economic Implications: A Preliminary Analysis”. Pakistan Development Review. Vol. XIII, No. 3. Autumn 1974. pp. 245-279.

48. Hirashima, S. The Structure of Disparity in Developing Agriculture. Tokyo: Institute of Developing Economies. 1978.

49. Hussain, S. M. "Price Incentives for the Production of High-Yielding Mexican Varieties of Wheat". Pakistan Development Review. Vol. X, No.4. Winter 1970. pp. 448-467.

50. Hussain, S. M., and M. I. Khan (Editors). Empirical Studies on Pakistan Agriculture. Karachi: Pakistan Institute of Development Economics. 1970. (Readings in Development Economics No. 3)

51. Jamot, Z. A. "Impact on Socio-Economical Development". Pakistan Economist. Issue 46. November 17, 1979. pp. 13-15.

52. Johnston, B.F., and J. Cownie. "The Seed-Fertilizer Revolution and Labor Force Absorption”. American Economic Review. Vol. 59, No. 4. 1969. pp. 569-582.

53. Kaneda, H. "Economic Implications of the 'Green Revolution' and the Strategy of Agricultural Development in West Pakistan”. Pakistan Development Review. Vol. IX, No.2. Summer 1969. pp. 111-143.

54. Kaneda, H., and M. Ghaffar. "Output Effects of Tubewells on the Agriculture of the Punjab”. Pakistan Development Review. Vol. X, No. 1. Spring 1970. pp. 68-87.

55. Khan, M. H. "Farm Size and Land Productivity Relationships in Pakistan". Pakistan Development Review. Vol. XVIII, No. 1. Spring 1979. pp. 69-76.

56. Khan, M. H. "Land Productivity, Farm Size and Returns to Scale in Pakistan Agriculture". World Development. Vol. 5, No. 4. 1977. pp. 317-323.
57. Khan, M. H. The Economics of the Green Revolution in Pakistan. New York: Praeger Publishers. 1975.

58. Khan, M. H. Underdevelopment and Agrarian Structure in Pakistan. Boulder Colorado: Westview Press. 1981.

59. Khan, M. H., and D. R. Maki. "Effects of Farm Size on Economic Efficiency: The Case of Pakistan". American Journal of Agricultural Economics Vol. 61, No. 1. 1979. pp. 64-69.

60. Khan, M. H., and D. R. Maki. "Relative Efficiency by Farm Size and the Green Revolution in Pakistan". Pakistan Development Review. Vol. XIX, No. 1. Spring 1980. pp. 51-64.

61. Khuro, M. A. "Letter to the Editor". (The daily) Dawn, Karachi. July 14, 1978. p. 8

62. Lewis, S. R. Jr. Economic Policy and Industrial Growth in Pakistan. London: Allen and Unwin. 1969.

63. Lowdermilk, M. K. "Diffusion of Dwarf Wheat Technology in Pakistan's Punjab”. Unpublished Ph. D. Thesis. Cornell University. 1972.

64. McEwan, A. Development Alternatives in Pakistan. Cambridge, Mass: Harvard University Press. 1971

65. McEwan, A. "Problems of Interregional and Intersectoral Allocation: The Case of Pakistan". Pakistan Development Review. Vol. X, No. 1. Spring 1970. pp. 1-23.

66. Mohammad, G. "Private Tubewell Development and Cropping Patterns in West Pakistan". Pakistan Development Review. Vol. V, No. 1. Spring 1965. pp. $1-53$.

67. Mohammad, G. "Some Physical and Economic Determinants of Cotton Production in West Pakistan". Pakistan Development Review. Vol. III, No. 4. Winter 1963. pp. 491-526.

68. Mohammad, G. "Some Strategic Problems in Agricultural Development in Pakistan”. Pakistan Development Review. Vol. IV, No. 2. Summer 1964 pp. $223-260$

69. Mohammad, G. "Waterlogging and Salinity in the Indus Plain: A Critical Analysis of Some of the Major Conclusions of the Revelle Report". Pakistan Development Review. Vol. IV, No.3. Autumn 1964. pp. 357-403.

70. Naseem, S. M. "Mass Poverty in Pakistan: Some Preliminary Findings". Pakistan Development Review. Vol. XII, No. 4. Winter 1973 pp. 317-360.

71. Naseem, S. M. “A National Profile of Poverty in Pakistan”. Bangkok. 1979 (Mimeographed)

72. Naseem, S. M. "Rural Poverty and Landlessness in Pakistan". In I.L.O., Poverty and Landlessness in Rural Asia. Geneva. 1977. pp. 41-60. 
73. Naseem, M. "Small Farmer and Agircultural Transformation in Pakistan Punjab". Unpublished Ph. D. Thesis. University of California. 1971.

74. Nulty, L. The Green Revolution in West Pakistan: Implications of Technological Change. New York: Praeger Publishers. 1972.

75. Pakistan Institute of Development Economics. An Abstract of Economic and Demographic Research. Islamabad. August 1974.

76. Pakistan Institute of Development Economics. A Report on the Seminar on the Current Economic Problems of Pakistan. Karachi. May 1967.

77. Pakistan Institute of Development Economics. The State of Pakistan's Economy, 1970-71 to 1979-80. Islamabad. 1980.

78. Pakistan. Planning Commission. The Fifth Five Year Plan (1978-83). Islamabad. June 1978.

79. Pakistan. Planning Commission. The Report of the Indus Basin Research Assessment Group. Islamabad. June 1978.

80. Pakistan. Taxation Enquiry Committee Report, 1960. Two Volumes. Karachi. 1963 and 1964.

81. Qureshi, S. K. "The Performance of Village Markets for Agricultural Produce: A Case Study of Pakistan”. Pakistan Development Review. Vol. XIII, No. 3. Autumn 1974. pp. 280-307.

82. Qureshi, S. K. "Price Incentives for the Production of High-Yielding Varieties of Wheat: A Comment". Pakistan Development Review. Vol. XI, No. 1. Spring 1971. pp. 54-62.

83. Qureshi, S. K. "Price Responsiveness of Marketed Surplus of Wheat in Pakistan". Pakistan Development Review. Vol. XIII, No. 2. Summer 1974. pp. 115-28.

84. Qureshi, S. K. "The Problem of Agricultural Taxation in Pakistan and an Alternative Solution: A Comment”. Pakistan Development Review. Vol. XII, No. 4. Winter 1973. pp. 433-437.

85. Qureshi, S. K. "Reliability of Pakistan's Agricultural Price Data”. Pakistan Development Review. Vol. XII, No.2. Summer 1973. pp. 168-180.

86. Qadeer, M. A., et al. An Evaluation of the Integrated Rural Development Programme. Islamabad: Pakistan Institute of Development Economics. 1977. (Monograph No. 19)

87. Raquibuzzaman, M. "Marketed Surplus Function of Major Agricultural Commodities in Pakistan”. Pakistan Development Review. Vol. VI, No. 3. Autumn 1966. pp. 376-394.

88. Rochin, R. I. "A Micro-Economic Analysis of Smallholder Response to HighYielding Varieties of Wheat in West Pakistan”. Unpublished Ph. D. Thesis. Michigan State University. 1971.

89. Saeed, N. "Land Reform in Pakistan". Islamabad: Ford Foundation. 1978. (Mimeographed)
90. Saeed, Z. "Growth of Crop Output in Pakistan - An Analysis by Component Elements”. Pakistan Development Review. Vol. XV, No. 3 Autumn 1976. pp. 319-329.

91. Salam, A. "Economic Analysis of Fertilizer Demand in the Punjab". Pakistan Development Review. Vol. XVI, No. 2. Summer 1977. pp. 181-191.

92. Salam, A. "Factor Inputs Use and Factor Productivity on Different Farm Categories in the Punjab". Pakistan Development Review. Vol. XVII, No. 3. Autumn 1978. pp. 316-332.

93. Salam, A. "Resource Productivity in Punjab Agriculture". Pakistan Development Review. Vol. XV, No. 2. Summer 1976. pp. 115-133.

94. Salam, A. "Technical Change, Tenant Displacement and Adjustment in Pakistan". Pakistan Development Review. Vol. XVI, No. 4. Winter 1977. pp. $435-448$.

95. Siddiqui, A. H. Agriculture in Pakistan: A Selected Bibliography, 1947 - 1969. Rawalpindi: U.S.A.I.D. 1969. (Mimeographed)

96. Siddiqui, A. H. The Economy of Pakistan: A Select Bibliography, 1947-1962. Karachi: Pakistan Institute of Development Economics. October 1963.

97. Takahashi, A. "Pakistan: Land Reforms from Above". In Z. M. Ahmed (Editor), Land Reforms in Asia, with Particular Reference to Pakistan, The Philippines and Thailand. Geneva: I.L.O. 1976. (WEP Study)

98. Thobani, M. "The Effects of a Change in Wheat Prices on Incomes". Pakistan Development Review. Vol. XVIII, No. 4. Winter 1979. pp. 283-312.

99. U.S. White House, Department of Interior Panel on Waterlogging and Salinity in West Pakistan. Report on Land and Water Development in the Indus Plain. (Revelle Report). Washington, D. C. January 1964.

100. West Pakistan. Land Commission. Land Reforms in West Pakistan. Vol. I Lahore. 1960.

101. West Pakistan. Land Commission. Land Reforms in West Pakistan. Vol. III. Lahore. 1968.

102. World Bank. The Consequences of Farm Tractors in Pakistan. Washington, D. C. February 1975. (Staff Working Paper No. 210)

103. Yasin, C. G. Private Tubewells in the Punjab. Lahore: Punjab Board of Economic Inquiry. 1975.

104. Yasin, C. G. Socio-Economic Effects of Land Reforms of 1959. Lahore: Punjab Board of Economic Inquiry. 1972. (Publication No. 151)

105. Yusuf, S. "Rural Social Relations and Agricultural Development in Pakistan". Unpublished Ph. D. Thesis. Harvard University. 1980.

106. Zahid, S. "Ushr: A Theoretical and Empirical Analysis". Discussion Paper No. 39. Applied Economics Research Centre. University of Karachi. 1980. 